\title{
ENHANCED EFFICACY OF SUBLINGUAL IMMUNOTHERAPY IN CHILDHOOD ALLERGIC ASTHMA BY PROBIOTICS
}

\author{
Anang Endaryanto, Mira Irmawati \\ Department of Child Health, Faculty of Medicine, Universitas Airlangga, Dr. Soetomo Hospital, Surabaya, Indonesia
}

\begin{abstract}
ABSTRAK
Probiotik diharapkan dapat berperan secara sinergis untuk meningkatkan efektifitas klinis imunoterapi sublingual (SLIT). Tujuan penelitian ini adalah untuk mengetahui peran probiotik dalam peningkatan efektivitas imunoterapi sublingual pada asma alergi anak. Penelitian klinis acak buta tunggal ini dilakukan pada anak-anak asma alergi yang berusia 6-17 tahun yang sensitif terhadap alergen debu rumah. Subyek dialokasikan ke dalam kelompok A yang menerima SLIT saja, kelompok B yang menerima SLIT bersama probiotik, dan kelompok $C$ yang hanya menerima probiotik. Parameter klinis (reversibilitas FEV $V_{l}$, skor pengobatan, dan skor gejala) serta parameter imunologis (jumlah IgE, eosinofil, IFN- $\gamma$, IL-2, IL-4, IL5, IL10, dan TGF- $\beta$ ) dievaluasi pada minggu ke0 sampai 14.Hasil analisis statistik menunjukkan bahwa tidak ada perbedaan signifikan antar kelompok dalam parameter klinis (reversibilitas $F E V_{l}$, skor pengobatan, dan skor gejala). Perbedaan antar kelompok dalam parameter imunologis dalam hal IgE total, IFN- $\gamma$, IL-2, IL-4, IL5, IL10, dan TGF- $\beta$ juga tidak signifikan. Jumlah eosinophil menurun pada subyek yang mendapat kombinasi SLIT dengan probiotik.Kesimpulan dari penelitian ini adalah probiotik dapat meningkatkan efektivitas imunoterapi sublingual pada asma alergi anak melalui penurunan jumlah eosinofil. (FMI 2018;54:64-74)
\end{abstract}

Kata kunci: Alergi asma; imunoterapi sublingual; probiotik; efektivitas

\begin{abstract}
It is expected that probiotics may act synergistically to improve the clinical efficacy of sublingual immunotherapy (SLIT). The aim of this study was to investigate the role of probiotics in enhancing efficacy of sublingual immunotherapy in childhood allergic asthma. This was a randomized single blind clinical trial conducted on 6-17 year-old asthmatic children sensitive to house dust mite allergens. Subjects were allocated to Group A receiving SLIT, Group B receiving probiotics and SLIT, Group C receiving probiotics only. Clinical parameters ( $F E V_{1}$ reversibility, medication score, and symptom score) and immunological parameters (total IgE, eosinophil count, IFN- $\gamma, I L-2, I L-4, I L 5, I L 10$, and TGF- $\beta$ were evaluated in week 0 until 14. Statistical analysis revealed that the difference of clinical parameters (FEV reversibility, medication score, and symptom score) between groups were not significant. The difference of the immunological parameters of total IgE, IFN- $\gamma, I L-2, I L-4, I L 5, I L 10$, and TGF- $\beta$ were also not significant. Eosinophil count decreased in subjects who received combination SLIT with probiotics. In conclusion, probiotics enhanced the efficacy of sublingual immunotherapy in childhood allergic asthma by decreasing the eosinophil count. (FMI 2018;54:64-74)
\end{abstract}

Keywords: Asthma allergy; sublingual immunotherapy; probiotics; efficacy

Correspondence: Anang Endaryanto, Jl. Opak 41 Surabaya, Indonesia. Phone: +62811327431, +62315676521.

Email: aendaryanto.ae@gmail.com

\section{INTRODUCTION}

The prevalence of IgE-mediated allergic diseases has increased more than two-fold during the last decades. Currently, more than $30 \%$ of the population in industrialized countries are allergic to aeroallergens such as house dust mites (Pfaar et al 2012, Upton et al 2000). Allergen-specific immunotherapy (AIT) is an effective therapy for IgE-mediated respiratory allergic diseases and has a potentially sustained effect after completed treatment (Durham 2011, Moingeon \& Mascarell 2012). Sublingual immunotherapy (SLIT), demonstrates safety and clinical efficacy with improvements on adverse events (Durham 2011, Moingeon \& Mascarell 2012, Canonica et al 2003, Durham et al
2012, Dahl et al 2006). SLIT has been shown to induce a shift from the allergy promoting Th2 cells (IL-4, IL-5, and IL-13) toward TH1 cells (IFN- $\gamma$ ), induce allergenspecific regulatory $\mathrm{T}$-cells, and produce allergenspecific IgA and IgG, mainly IgG4 (Allam et al 2011, Moingeon et al 2006, Radulovic et al 2008, Scadding et al 2010). Concomitantly with an increased efficacy, the number and severity of adverse events also increase with dose of SLIT. The target profile for an improved SLIT treatment is therefore improved safety with maintained or increased clinical efficacy, and increased patient convenience.

Pre-clinical studies have shown that probiotics could modulate the global immune response of the host, thus 
reducing sensitization and allergic inflammation (Sudo et al 1997, Geuking et al 2011). Many studies have suggested the hypothesis that probiotics might be protective for asthma. Specifically, in pediatric asthma LGG was reported to reduce the concentration of exhaled nitric oxide among 4- to 7-year-olds. Treatment with LGG has been shown to decrease MMP9 expression in lung tissue, to inhibit inflammatory cell infiltration, and to decrease the number of infiltrating inflammatory cells and Th2 cytokines in bronchoalveolar lavage fluid and serum (Wu et al 2016). Similar results have been reported with other probiotics (Elazab et al 2013). Bifidobacterium bifidum, B. lactis, and Lc. lactis were shown to have a good IL-10-inducing capacity and to exert a significant inhibition of Th2related cytokines IL-5 and IL-13 (Gorissen et al 2014, Niers et al 2005, Niers et al 2007). It is expected that probiotics may act synergistically to improve the clinical efficacy of sublingual immunotherapy.

The purpose of this study was to investigate the role of probiotics in enhancing efficacy of sublingual immunotherapy in childhood allergic asthma on clinical parameters (FEV 1 reversibility, medication score, and symptom score) and immunological parameters (total IgE, eosinophil count, IFN- $\gamma$, IL-2RB, IL-4, IL5, IL10, and TGF- $\beta$ ).

\section{MATERIALS AND METHODS}

\section{Participants and study design}

This clinical trial was a randomized study conducted at an allergic clinic of the Child Health Department, Soetomo General Hospital from September 01, 2008 to March 31, 2012. Informed written consents were obtained from each patient or their legal guardians. Subject has a willingness to participate as indicated by a signed and dated informed consent form, by parent or guardian, prior to undergoing any study-related procedures or medication withdrawal. A written informed assent form, signed by the child, if old enough to understand the research nature of the study, would also be obtained, where practical. This study was approved by the Hospital Ethics Committee.

The investigation took place during fourteen clinical visits (screening, and visits 1 to 14). During the screening visit, general data, including name, address, age, gender, body weight, body height and telephone number, were collected and recorded for all the participants. A comprehensive medical and allergy history was obtained for all subjects, especially pertaining to the allergic asthma and its duration, as well as details of family allergies and control medications. Blood samples were taken before the study for measurement of total $\operatorname{IgE}$ and specific $\operatorname{IgE}$ skin test to five allergens. The subjects, of both sexes, were 6-17 years of age and had a diagnosis of asthma as defined by the American Thoracic Society (ie, "a disease characterized by increased responsiveness of the trachea and bronchi to various stimuli and manifested by widespread narrowing of the airway that changes in severity, either spontaneously or as a result of therapy") (1) for $\geq 3$ months. Subjects 6-11 years of age must have a prebronchodilator forced expiratory volume in 1 second $\left(\mathrm{FEV}_{1}\right)$ of $\geq 75 \%$ and $\leq 90 \%$ of Polgar predicted normal value at Visit 1. Subjects 12-17 years of age, must have a pre-bronchodilator forced expiratory volume in 1 second $\left(\mathrm{FEV}_{1}\right)$ of $\geq 60 \%$ and $\leq 90 \%$ of Polgar predicted normal value at Visit 1. Subjects with predicted $\mathrm{FEV}_{1}$ of $>90 \%$ and $\leq 95 \%$ may be included if they have an absolute $\mathrm{FEV}_{1} / \mathrm{FVC}$ ratio measured on screening spirometry of $<80 \%$. Reversibility criteria were defined as an increase in $\mathrm{FEV}_{1} \geq 12 \%$ from pre-bronchodilator $\mathrm{FEV}_{1}, 15-30$ minutes after 2 actuations of a salbutamol pMDI $(100 \mu \mathrm{g} /$ actuation $)$, performed at Visit 1 . All patients showed sensitization to house dust mites (DP), as evaluated by skin testing (wheal $\geq 3 \mathrm{~mm}$ ).

Exclusion criteria for the subjects consisted of lifethreatening asthma; two or more hospitalizations for asthma within 1 year of Visit 1 or any emergency room; Visit for asthma within 6 months of Visit 1; using steroids during the month (28 days) prior to Visit 1 or at any time during the trial, using leukotriene modifiers or ketotifen (oral), within 2 weeks prior to Visit 1; with any history of smoking, with any clinically relevant respiratory diseases such as cystic fibrosis, bronchopulmonary dysplasia (BPD), interstitial lung disease or active or untreated pulmonary tuberculosis; have past or present diseases of the cardiovascular, endocrine, renal, hepatic, gastrointestinal, neurological, musculoskeletal, or metabolic systems or other medical conditions considered clinically significant; with a history of malignancy in the past 5 years; with a planned hospitalization during the study; with known hypersensitivity to salbutamol and excipients; has severe asthma, as judged by the investigators; and previously diagnosed with neuropsychiatric or congenital immunodeficiency or probiotics allergy.

Specific reasons for discontinuing a subject from this study are: withdrawal of informed consent; intolerable adverse event (AE); use of disallowed medication; pregnancy; incorrect randomization; decrease in $\mathrm{FEV}_{1}$ (L) $\geq 25 \%$ from Visit 1 or to below $40 \%$ of predicted; use of 12 or more actuations of salbutamol pMDI per day for 2 days within a 3 day period; three nighttime awakenings requiring treatment with short-acting 
inhaled $\beta_{2}$-agonist within a 5-day period; and not maintaining at least $80 \%$ data entry compliance.

After enrollment at visit 1 (baseline), subjects were randomly assigned to one of three groups ( $\mathrm{A}=\mathrm{SLIT}$ alone, $\mathrm{B}=$ Probiotics together with SLIT and $\mathrm{C}=$ Probiotics alone). Each subject should be seen at approximately the same time of day for each visit, starting with Visit 1. For each clinical assessment and individual subject, the assessment should be performed using the same equipment, relevant for the assessment, at all Visits. Lung function tests should be performed between 6:00 9:30 AM for \pm 30 minutes, and for the individual subject, each test should be performed \pm 60 minutes from the time the test was performed at Visit 1 . If necessary due to scheduling, sites may conduct Visit 1 Pulmonary Function Tests on a separate day than the remainder of Visit 1 procedures. The Pulmonary Function Tests should not be more than 3 days before or after the remainder of the Visit 1 procedures.

\section{Visit 1}

All subjects were asked to supply certain information and underwentstudy tests and procedures as follows: reading and signing informed consent/assent (with parental or guardian assistance, as needed); providing oral consent/assent; medical/medication history; pulmonary function testing; clinical chemistry, hematology, cytokine, urinalysis; and complete physical examination.

\section{Visit 2 to visit 13}

If the subject metall inclusion criteria and none of the exclusion criteria previously described, the following tests and procedures were verified that the subject did not meet the discontinuation criteria established; concomitant medication and adverse event query; review diary data to ascertain eligibility; pulmonary function testing; mouth examination; dispense study drug, and instruct the subject regarding the dosing regimen.

\section{Visit 14}

The following tests and procedures were performed at Visit 14 verifying that the subject did not meet the discontinuation criteria; had completed physical examination including mouth examination; clinical chemistry, hematology, cytokine and urinalysis; concomitant medication and adverse event; pulmonary function testing; and diary data.

\section{Assessment of symptoms and drug scores}

Patients' diary cards recording symptoms and medication scores were used during the study for 14 weeks. The symptoms scores for asthma (cough and breathlessness) were separately recorded by each patient's parent and rated according to the following scale: $0=$ no symptoms; $1=$ mild symptoms; $2=$ moderate symptoms; $3=$ serious symptoms. For each patient, the total of medications taken daily (systemic antihistamines, nasal chromoglycate, ocular cromoglycate, and beta-2-agonist) were recorded in daily diary cards. Symptoms and medication scores were considered in each patient as monthly cumulative values obtained by summing-up the scores recorded daily.

\section{The efficacy variables}

The primary efficacy variable was the change from baseline in $\mathrm{FEV}_{1}$ reversibility in \% of predicted normal value measured at the clinic Visits. Secondary efficacy variables were nighttime and daytime asthma symptom scores, rescue medication use (number of puffs per day and number of days used), change from baseline in total IgE, eosinophil count, IFN- $\gamma$, IL-2RB, L-4, IL5, IL10, and TGF- $\beta$.

\section{Safety variables}

Safety variables included the incidence of adverse events, discontinuations due to adverse events, serious adverse events, laboratory evaluations, and physical examinations.

\section{Sublingual Immunotherapy Drug and Dose}

NOVO-HELISEN ORAL (Germany) allergen extract of house dust mite was used for sublingual immunotherapy. The composition of the allergens is listed on the labels. Novo-Helisen ${ }^{\circledR}$ oral is standardized in TU (therapeutic units) or in PNU (protein nitrogen units). Strength 2 of Novo-Helisen oral is a 1:10 dilution of strength 3 , strength 1 is a $1: 10$ dilutionof strength 2 and strength 0 is a $1: 10$ dilution of strength 1.Initial treatment set: 3 vials of strength 1, 2, 3 vials of strength 1, 2, 3 with $30 \mathrm{ml}$ each. Maintenance treatment set: 3 vials of strength 3 or 1 vial of strength 3 (on special request) with $30 \mathrm{ml}$ each.Treatment begins with 1 drop of the weakest concentration (strength 1). This dose is increased by 1 drop daily. Once the dose of 28 drops a day has been reached, treatment is continued with 2 drops of the next highest concentration (strength 2). This dose is again increased by 1 drop daily until 28 drops of strength 2 are reached. Treatment is then continued with 2 drops of strength 3 , again increased daily by 1 drop until the maximum dose of 28 drops of strength 3 is reached. 


\section{Probiotics}

Each capsule contained Lactobacillus rhamnosus GG 5 $\times 10^{9}$ cfu, Bifidobacterium longum $2 \times 10^{9} \mathrm{cfu}$, and Bifidobacterium bifidum $2 \times 10^{9}$ cfu. The study preparation was manufactured by Outpatient Allergy Clinic Dr. Soetomo General Hospital. Each dose was stored in airtight alu-bags at $-20^{\circ} \mathrm{C}$ until the first day of the intervention period. During the 14 weeks study period, the patients were asked to abstain from any fermented food products containing live microorganisms and none of the patients changed diet during the study period. Issues regarding taste of the test preparation and the child's preferred way to ingest the powder were discussed at each scheduled visit.

\section{Statistical analysis}

The primary outcome measure was change in symptom score from baseline following treatment. The sample size of 30 patients provided sufficient power $(90 \%)$ to detect a difference of $10 \%$ between 3 groups $(\alpha=0.05)$. Statistical analysis was performed by means of multivariate analysis. for intra- and inter-group analysis, respectively. All lost rates, missing values and reasons for drop out or premature termination of the study was recorded. The SPSS software was used for data management and statistical analysis. Data were presented as mean \pm SD and $\mathrm{p}$ values of 0.05 or less were considered as statistically significant.

\section{RESULTS}

\section{Demographic Characteristics}

In total, 50 subjects were enrolled during their screening visit; 32 fulfilled the inclusion criteria and were randomized into three groups, $\mathrm{A}, \mathrm{B}$, and $\mathrm{C}$, receiving SLIT alone and SLIT combined with probiotics and probiotics alone, respectively. Patient demographics and baseline characteristics were similar for the three groups (Table 1). Although intra-group comparisons showed some differences, these differences did not reach statistical significance. There were no significant between-group differences in sensitization rate to the five allergens. No participants left the trial prematurely due to adverse effects or other factors (such as poor compliance or moving away) or failed to finish the diary book questionnaires.

\section{Clinical scores and efficacy}

Symptom scores for asthma and drug usage were not different at baseline visit (pre treatment) and at the post treatment between group A, B and C (Table 1). Similar- ly, all of therapy groups had no differences on the decreasing of the symptoms, drug usage and FEV 1 reversibility in the post treatment (Table 2).

\section{Laboratory parameters}

The reduction of total IgE, eosinophil count, IL-4 and IL-5 observed in the group Awere also observed in the group $\mathrm{B}$ and group $\mathrm{C}$. There were no differences in the reduction of total IgE, IL-4 and IL-5 between group A, $\mathrm{B}$ and $\mathrm{C}$. The decreasing of eosinophil count was significantly different between group A, B and C. IFN- $\gamma$, IL2 , IL-10 and TGF- $\beta$ increased in all of the groups and there was no significant difference between them (Table 3).

\section{DISCUSSION}

We have shown prospectively that probiotics enhance the efficacy of sublingual immunotherapy (SLIT). SLIT is a safe and effective alternative to injective immunotherapy (Tari et al 1990, Troise et al 1995, Sabbah et al 1994, Clavel et al 1998, Feliziani et al 1995, Quirino et al 1996, Passalacqua et al 1998, Vourdas et al 1998, Bousquet et al 1999, Canonica et al 2003, Bousquet et al 1998). World Health Organization (WHO) and Allergic Rhinitis and its Impact on Asthma (ARIA) recognized SLIT as an efficacious treatment for seasonal allergies (Bousquet et al 1998, Bousquet et al 2001).

The original rationale for administering immunotherapy sublingually was that of achieving a prompt and rapid absorption of the vaccine to avoid possible gastrointestinal degradation. Although it was recently demonstrated that no relevant direct absorption through the sublingual mucosa occurs, SLIT proved effective in a great number of trials; therefore, it is presently the most widely used non-injection route for immunotherapy in Europe. About 22 DBPC trials (Tari et al 1990, Sabbah et al 1994, Feliziani et al 1995, Troise et al 1995, Hirsch et al 1997, Clavel et al 1998, Horak et al 1998, Vourdas et al 1998, Hordijk et al 1998, Passalacqua et al 1998, Passalacqua et al 1999, Bousquet J et al 1999, Purello et al 1999, Pradalier et al 1999, La Rosa et al 1999, Guez et al 2000, Pajno et al 2000, Caffarelli et al 2000, Ariano et al 2001, Bahcecilier et al 2001, Voltolini et al 2001, Lima et al 2002) conducted with adequate methods and analysis have been published in peer-reviewed journals and the magnitude of the clinical efficacy ranged between about $20 \%$ and $50 \%$ reduction of symptom or medication scores, thus quite superior to the placebo effect and close to the effect of subcutaneous immunotherapy (SCIT). SLIT exerts its effect on asthma symptoms. The results from some studies (Bousquet et al 1999, Purello 
et al 1999, Pradalier et al 1999, La Rosa et al 1999, Guez et al 2000, Pajno et al 2000) showed a reduction of the days with asthma symptoms (Pradalier et al 1999), of the use of 2-agonists (Bousquet et al 1999, Pradalier et al 1999) of the intake of systemic steroids (Guez et al 2000), and of clinical symptoms (Bousquet et al 1999, Pradalier et al 1999). One single study also demonstrated the measurable effect of SLIT on the quality of life of patients (Bousquet et al 1999). In our study, we have shown that SLIT alone and SLIT combined with probiotics could decrease asthma symptoms and drug usage including symptomatic and 2-agonists.
The immunological aspects of SLIT are not still clear (Lichtenstein et al 1973, Creticos et al 1985, Secrist et al 1995, Varney et al 1993). Many studies on SLIT have focused on possible decrease of serum $\operatorname{IgE}$ or/and increase of IgG1 and IgG4, but these changes were not constant and reproducible (Allam et al 2011, Moingeon et al 2006, Radulovic et al 2008, Scadding et al 2010, Fanta et al 1999). SLIT has been proved to reduce intercellular adhesion molecule 1 expression on nasalepithelial cells and to decrease methacholine responsiveness (Silvestri et al 2002). Our study showed that SLIT could decrease serum IgE, eosinophil count, TH2 cytokines level (IL-4 and IL-5) and increase TH1 cytokines level (IFN- $\gamma$ and IL-2) and T regulator cytokines (IL-10 and TGF- $\beta$ ).

Table 1. Demographic characteristics at the baseline visit

\begin{tabular}{|c|c|c|c|c|}
\hline Variables & $\begin{array}{c}\text { Group A } \\
\text { (SLIT) } \\
n=11\end{array}$ & $\begin{array}{c}\text { Group B } \\
\begin{array}{c}\text { (SLIT+Probiotics) } \\
n=11\end{array}\end{array}$ & $\begin{array}{c}\text { Group C } \\
\text { (Probiotics) } \\
n=10\end{array}$ & $\mathrm{p}$ value \\
\hline Age, mean (SD) yrs & $9.09(2.30)$ & $8.82(2.18)$ & $9.10(2.30)$ & 0.945 \\
\hline $\mathrm{BW}$, mean (SD) kg & $28.55(11.83)$ & $29.36(11.73)$ & $28.50(5.02)$ & 0.976 \\
\hline $\mathrm{BH}$, mean $(\mathrm{SD}) \mathrm{cm}$ & $131.73(17.55)$ & $130.45(12.77)$ & $131.30(11.99)$ & 0.978 \\
\hline Total-IgE, mean (SD)IU/ml & $414.91(358.15)$ & $220.45(244.30)$ & $426.70(277.49)$ & 0.213 \\
\hline Eosinophil Count, mean (SD) /cmm & $508.64(249.22)$ & $440.45(224.56)$ & $532.50(281.75)$ & 0.685 \\
\hline FEV 1 reversibility, mean (SD) \% & $17.71(4.52)$ & $17.61(4.96)$ & $20.59(12.03)$ & 0.618 \\
\hline \multicolumn{5}{|l|}{ Gender } \\
\hline Male & $7(63.6)$ & $3(27.3)$ & $4(40.0)$ & 0.219 \\
\hline Female & $4(36.4)$ & $8(72.7)$ & $6(56.3)$ & \\
\hline \multicolumn{5}{|l|}{ FH of Allergy } \\
\hline Yes & $1(9.1)$ & $2(18.2)$ & $1(10.0)$ & 0.779 \\
\hline No & $10(90.9)$ & $9(81.8)$ & $9(90.0)$ & \\
\hline \multicolumn{5}{|l|}{ Feather } \\
\hline Yes & $2(18.2)$ & $2(18.2)$ & $1(10.0)$ & 0.840 \\
\hline No & $9(81.8)$ & $9(81.8)$ & $9(90.0)$ & \\
\hline \multicolumn{5}{|l|}{ Egg white } \\
\hline Yes & $5(45.5)$ & $6(54.5)$ & $7(70.0)$ & 0.521 \\
\hline No & $6(54.5)$ & $5(45.5)$ & $3(30.0)$ & \\
\hline \multicolumn{5}{|l|}{ Cow's Milk } \\
\hline Yes & $10(90.9)$ & $9(81.8)$ & $8(80.0)$ & 0.757 \\
\hline No & $1(9.1)$ & $2(18.2)$ & $2(20.0)$ & \\
\hline \multicolumn{5}{|l|}{ Shrimp } \\
\hline Yes & $9(81.8)$ & $10(90.9)$ & $8(80.0)$ & 0.757 \\
\hline No & $2(18.2)$ & $1(9.1)$ & $2(20.0)$ & \\
\hline Der p $1 \varnothing$ wheal, mean (SD) mm & $10.18(3.97)$ & $7.18(4.21)$ & $9.40(3.24)$ & 0.185 \\
\hline$\varnothing$ flare, mean (SD) mm & $23.09(10.75)$ & $15.55(11.51)$ & $25.20(12.30)$ & 0.143 \\
\hline Der f $1 \varnothing$ wheal, mean (SD) mm & $8.09(3.67)$ & $6.09(2.07)$ & $7.50(1.72)$ & 0.211 \\
\hline$\varnothing$ flare, mean (SD) mm & $18.91(8.50)$ & $14.00(5.35)$ & $19.10(6.57)$ & 0.172 \\
\hline
\end{tabular}


Table 2. Clinical score at the baseline visit and at the post treatment

\begin{tabular}{|c|c|c|c|c|}
\hline Variables & $\begin{array}{c}\text { Group A } \\
\text { (SLIT) } \\
n=11\end{array}$ & $\begin{array}{c}\text { Group B } \\
\text { (SLIT+Probiotics) } \\
\mathrm{n}=11\end{array}$ & $\begin{array}{c}\text { Group C } \\
\text { (Probiotic) } \\
n=10\end{array}$ & $\mathrm{P}$ value \\
\hline \multicolumn{5}{|l|}{ Symptom Score } \\
\hline Pre, mean (SD) & $51.73(42.57)$ & $31.91(28.21)$ & $46.40(37.70)$ & 0.434 \\
\hline Post, mean (SD) & $17.64(17.33)$ & $13.09(16.26)$ & $13.60(11.11)$ & 0.751 \\
\hline Pre-post difference, mean (SD) & $34.09(36.09)$ & $18.82(21.02)$ & $32.80(39.53)$ & 0.496 \\
\hline \multicolumn{5}{|l|}{ Drug Score } \\
\hline Pre, mean (SD) & $26.36(29.28)$ & $13.18(11.80)$ & $14.30(10.74)$ & 0.233 \\
\hline Post, mean (SD) & $5.64(9.84)$ & $6.55(8.32)$ & $7.80(7.44)$ & 0.848 \\
\hline Pre-post difference, mean (SD) & $20.73(25.42)$ & $6.64(13.03)$ & $6.50(13.15)$ & 0.134 \\
\hline \multicolumn{5}{|l|}{$\mathrm{FEV}_{1}$ reversibility } \\
\hline Pre, mean (SD) \% & $17.71(4.52)$ & $17.61(4.96)$ & $20.59(12.03)$ & 0.618 \\
\hline Post, mean (SD) \% & $3.83(1.79)$ & $2.91(1.83)$ & $4.85(3.54)$ & 0.852 \\
\hline Pre-post difference, mean (SD) \% & $13.88(4.97)$ & $14.70(4.60)$ & $15.74(11.42)$ & 0.218 \\
\hline
\end{tabular}
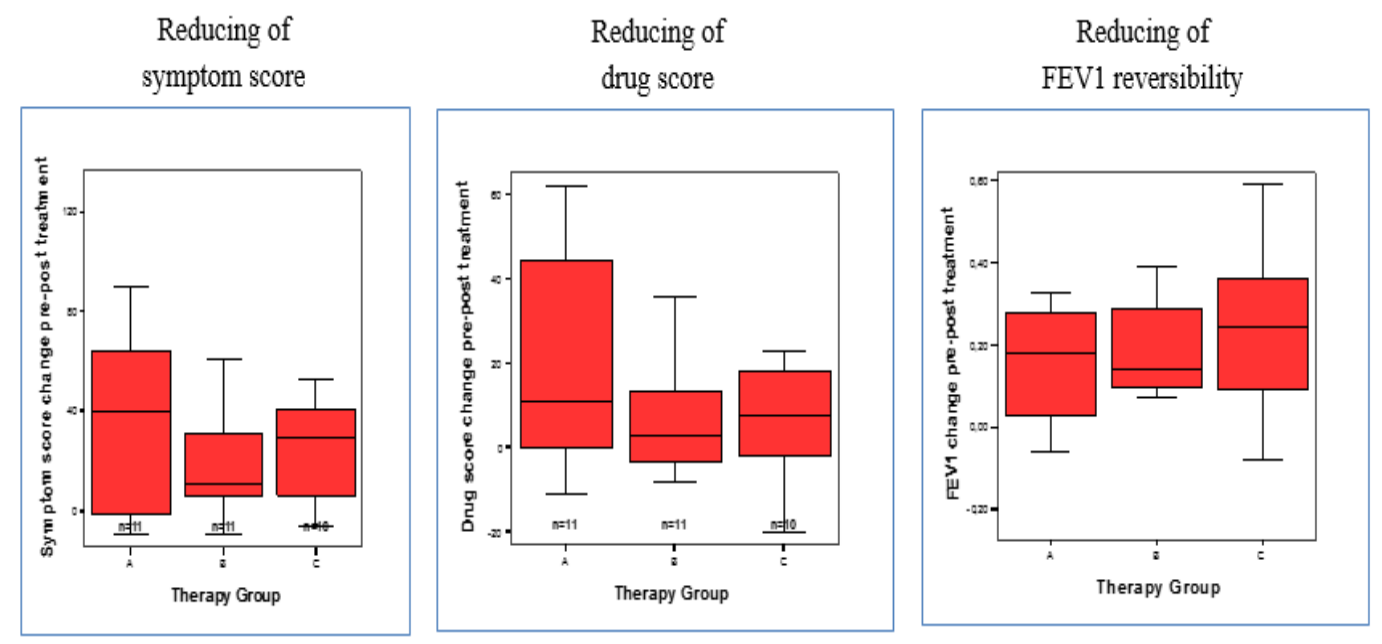

Fig. 1. Clinical outcome of three groups therapy (Group A receiving SLIT alone; Group B receiving SLIT combined with probiotic; and Group $\mathrm{C}$ receiving probiotics alone). Reducing of symptom scores, drug usage and FEV 1 reversibility were not different at baseline visit (pre treatment) and at the post treatment between these groups.

Many investigators have reported that probiotics and related products have beneficial effects for allergy sufferers (Isolauri 2001, Matricardi et al 2003). Our results also demonstrate that live probiotics may alleviate the symptoms caused by allergic asthma. Many previous studies reported that probiotics bacteria, which beneficially affect the host by improving its microbial balance (Fuller 1991), mediate antiallergenic effects by stimulating production of Th1-cytokines (Lombardi et al 2001, Lichtenstein et al 1973), TGF-B (Isolauri et al 2000, Paganelli et al 2002) and gut IgA (Fukushima et al 1999, Kirjavainen et al 1999). Our study also have shown that probiotics may mediate antiallergenic effects as good as sub-lingual immunotherapy (SLIT) or SLIT combined with probiotics by stimulating Th1-cytokines, IL-10 and TGF- $\beta$ and by decreasing Th2-cytokines (Matsuzaki et al 2000). 

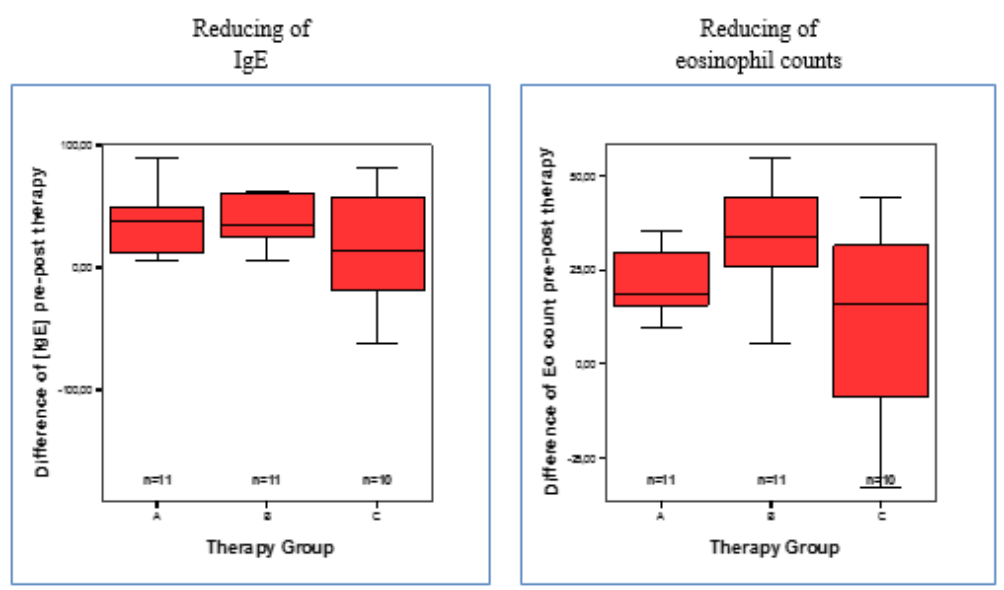

Fig. 2. Reducing IgE and eosinophil counts of three groups of therapy (Group A receiving SLIT alone; Group B receiving SLIT combined with probiotic; and Group C receiving Probiotics alone). Reducing of IgE were not different at baseline visit (pre treatment) and at the post treatment between these groups. There was significant difference in eosinophil count between Group B (SLIT combined with probiotic) and Group A or between Group B and Group C.
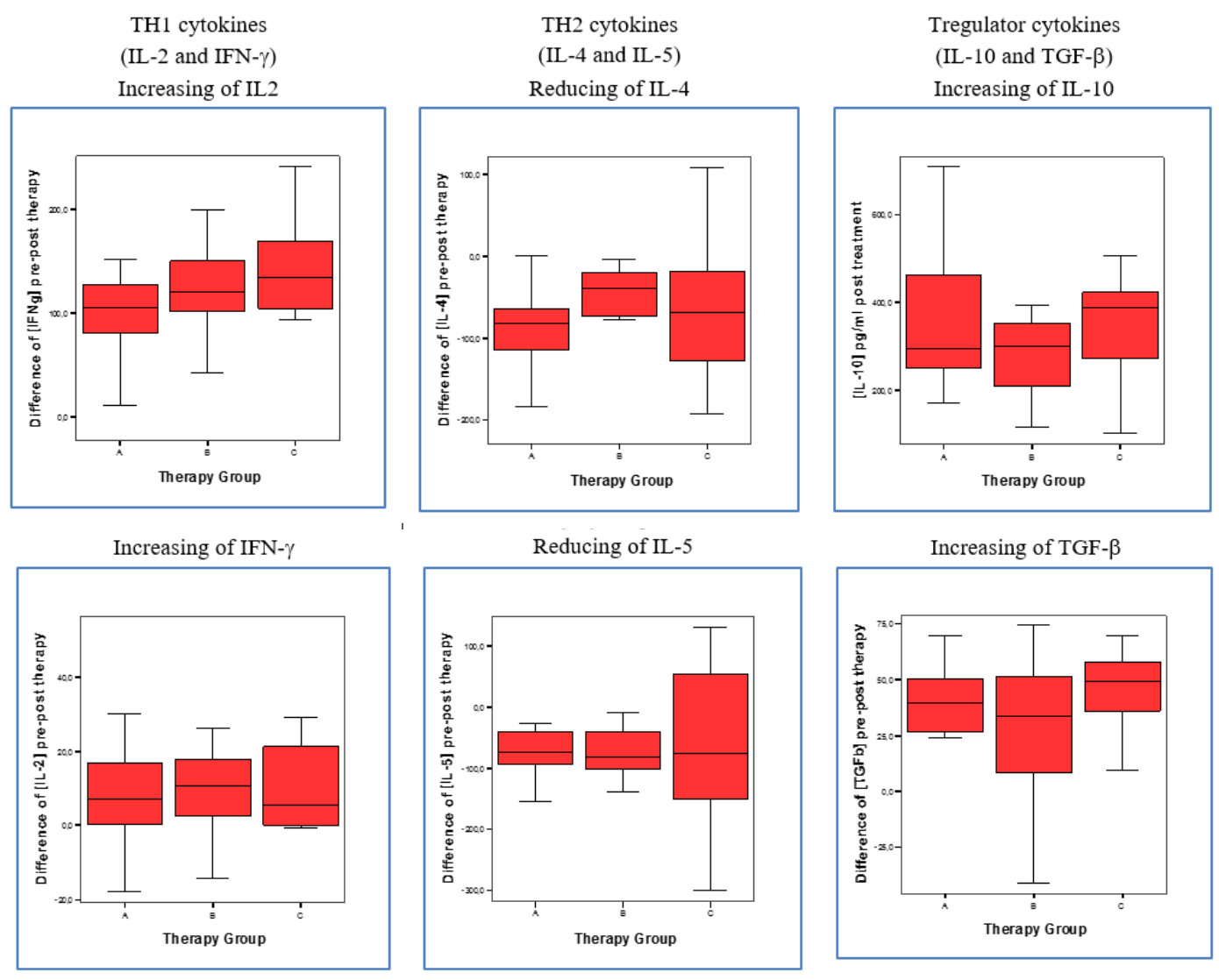

Fig. 3. Profile of TH1, TH2 and T-regulator change of three groups therapy (Group A receiving SLIT alone; Group B receiving SLIT combined with probiotic; Group C receiving Probiotics alone). Reducing ofTH2 cytokine (IL-4 and IL-5), increasing of TH1 cytokine (IFN- $\gamma$ and IL-2) and T-regulator (IL-10 and TGF- $\beta$ were not different at baseline visit (pre treatment) and at the post treatment between these groups. 
Table 3. Laboratory parameters at the baseline visit and at the post treatment

\begin{tabular}{|c|c|c|c|c|}
\hline Variables & $\begin{array}{c}\text { Group A } \\
\text { (SLIT) } \\
n=11\end{array}$ & $\begin{array}{c}\text { Group B } \\
\text { (SLIT+Probiotics) } \\
n=11\end{array}$ & $\begin{array}{c}\text { Group C } \\
\text { (Probiotic) } \\
n=10\end{array}$ & $P$ value \\
\hline \multicolumn{5}{|l|}{ IgE Total } \\
\hline Pre, mean (SD)IU/ml & $414.91(358.15)$ & $220.46(244.30)$ & $426.70(277.49)$ & 0.213 \\
\hline Post, mean (SD)IU/ml & $276.82(251.17)$ & $142.91(164.50)$ & $496.40(580.91)$ & 0.105 \\
\hline Pre-post difference, mean (SD) & $20.89(71.71)$ & $38.91(19.88)$ & $3.83(68.67)$ & 0.396 \\
\hline \multicolumn{5}{|l|}{ Eosinophil count } \\
\hline Pre, mean $(\mathrm{SD}) / \mathrm{cmm}$ & $669.82(349.35)$ & $679.46(365.40)$ & $588.70(281.44)$ & 0.798 \\
\hline Post, mean $(\mathrm{SD}) / \mathrm{cmm}$ & $508.64(249.22)$ & $440.46(224.56)$ & $532.50(281.75)$ & 0.685 \\
\hline Pre-post difference, mean(SD)/cmm & $23.00(17.23)$ & $34.38(15.55)$ & $9.81(26.91)$ & 0.033 \\
\hline \multicolumn{5}{|l|}{ IFN- $\gamma$} \\
\hline Pre, mean (SD)IU/ml & $35.67(27.07)$ & $37.20(26.53)$ & $39.92(17.01)$ & 0.921 \\
\hline Post, mean (SD)IU/ml & $133.03(61.44$ & $150.67(61.84)$ & $185.26(39.11)$ & 0.111 \\
\hline Pre-post difference,mean(SD)IU/ml & $97.36(44.49)$ & $113.47(57.44)$ & $145.34(46.12)$ & 0.100 \\
\hline \multicolumn{5}{|l|}{ IL-2 } \\
\hline Pre, mean (SD)IU/ml & $19.00(18.05)$ & $21.18(10.62)$ & $21.38(10.24)$ & 0.903 \\
\hline Post, mean (SD)IU/ml & $29.76(19.29)$ & $30.78(10.88)$ & $31.78(16.08)$ & 0.958 \\
\hline Pre-post difference,mean (SD)IU/ml & $10.76(19.30)$ & $9.60(11.40)$ & $10.40(12.23)$ & 0.982 \\
\hline \multicolumn{5}{|l|}{ IL-4 } \\
\hline Pre, mean (SD)IU/ml & $165.95(108.64)$ & $149.16(91.70)$ & $203.63(95.99)$ & 0.450 \\
\hline Post, mean (SD)IU/ml & $77.49(92.54)$ & $84.84(74.39)$ & $144.20(50.26$ & 0.104 \\
\hline Pre-post difference, mean (SD)IU/ml & $-88.46(49.45)$ & $-64.33(70.55)$ & $-59.43(92.42)$ & 0.613 \\
\hline \multicolumn{5}{|l|}{ IL-5 } \\
\hline Pre, mean (SD)IU/ml & $187.16(91.04)$ & $173.75(81.47)$ & $243.84(131.81)$ & 0.273 \\
\hline Post. mean (SD)IU/ml & $110.12(92.66)$ & $101.31(62.79)$ & $176.36(71.46)$ & 0.069 \\
\hline Pre-post difference, mean (SD)IU/ml & $-77.04(44.13)$ & $-72.44(44.58)$ & $-67.48(130.81)$ & 0.965 \\
\hline \multicolumn{5}{|l|}{ IL-10 } \\
\hline Pre, mean (SD)IU/ml & $114.36(120.38)$ & $76.89(87.93)$ & $141.40(159.29)$ & 0.499 \\
\hline Post, mean (SD)IU/ml & $369.00(183.91)$ & $282.04(90.45)$ & $347.66(117.14)$ & 0.316 \\
\hline Pre-post difference,mean (SD) IU/ml & $254.64(111.44)$ & $205.15(143.70)$ & $206.26(231.63)$ & 0.737 \\
\hline \multicolumn{5}{|l|}{ TGF- $\beta$} \\
\hline Pre, mean (SD)IU/ml & $52.04(28.85)$ & $34.91(29.60)$ & $24.34(19.83)$ & 0.071 \\
\hline Post, mean (SD)IU/ml & $89.89(27.35)$ & $63.47(23.78)$ & $69.96(17.86)$ & 0.035 \\
\hline Pre-post difference,mean (SD)IU/ml & $37.86(22.50)$ & $28.56(35.730$ & $45.62(20.15)$ & 0.368 \\
\hline
\end{tabular}

We have also shown prospectively that probiotics enhanced the efficacy of sublingual immunotherapy (SLIT) by decreasing blood eosinophil count. Asthma patients with greater blood eosinophil experience have more severe exacerbations and have poorer asthma control. Furthermore, a count-response relation exists between blood eosinophil counts and asthma-related outcomes. Blood eosinophil counts could add predictive value to Global Initiative for Asthma control-based risk assessment (Price et al 2015).

\section{CONCLUSION}

Probiotics enhanced the efficacy of sublingual immunotherapy in childhood allergic asthma by decreasing blood eosinophil count. This finding is important to prevent more severe asthma exacerbation and poorer asthma control in the future.

\section{ACKNOWLEDGMENTS}

We wish to thank all residents and medical staff at the Child Health Department of Medical Faculty Airlangga University, Dr. Soetomo General Hospital for following up all of the subjects in this study.

\section{REFERENCES}

Allam J-P, Novak N (2011). Local immunological mechanisms of sublingual immunotherapy. Curr Opin Allergy Clin Immunol 11, 571-578

Ariano R, Spadolini I, Panzani RC (2001). Efficacy of sublingual specific immunotherapy in Cupressaceae allergy using an extract of Cupressus arizonica: a double blind study. Allergol Immunopathol (Madr) 29, 238-44

Bahcecilier NN, Isik U, Barlan IB, Basaran N (2001). Efficacy of sublingual immunotherapy in children 
with asthma and rhinitis: a double-blind, placebocontrolled study. Pediatr Pulmonol 32, 49-55

Bousquet J, Lockey R, Malling HJ (1998). Allergen immunotherapy: therapeutic vaccines for allergic diseases. A WHO position paper. J Allergy Clin Immunol 102, 55862

Bousquet J, Scheinmann P, Guinnepain MT, et al (1999). Sublingual swallow immunotherapy (SLIT) in patients with asthma due to house dust mites: a double blind placebo controlled study. Allergy 54, 249-60

Caffarelli C, Sensi LG, Marcucci F, Cavagni C (2000). Preseasonal local allergoid immunotherapy to grass pollen in children: a double-blind, placebo-controlled, randomized trial. Allergy 55, 1142-7

Canonica GW, Passalacqua G (2003). Noninjection routes for immunotherapy. J Allergy Clin Immunol $111,437-448$

Clavel R, Bousquet J, Andre C (1998). Clinical efficacy of sublingual-swallow immunotherapy: a doubleblind, placebo-controlled trial of a standardized fivegrass-pollen extract in rhinitis. Allergy 53, 493-8

Creticos PS, Adkinson NF Jr, Kagey-Sobotka A, et al (1985). Nasal challenge with ragweed pollen in hay fever patients. J Clin Invest 76, 2247-53

Dahl R, Kapp A, Colombo G, et al (2006). Efficacy and safety of sublingual immunotherapy with grass allergen tablets for seasonal allergic rhinocon-junctivitis. J Allergy Clin Immunol 118, 434-440

Durham SR (2011). Sustained effects of grass pollen AIT. Allergy 66, 50-52

Durham SR, Emminger W, Kapp A, et al (2012). SQstandardized sublingual grass immunotherapy: confirmation of disease modification 2 years after 3 years of treatment in a randomized trial. $\mathrm{J}$ Allergy Clin Immunol 129, 717-725

Elazab N, Mendy A, Gasana J, Vieira ER, Quizon A, Forno E (2013). Probiotics administration in early life, atopy, and asthma: a meta-analysis of clinical trials. Pediatrics 132, e666-76

Fanta C, Bohle B, Hirt W, et al (1999). Systemic immunological changes induced by administration of grass pollen allergens via the oral mucosa during sublingual immunotherapy. Int Arch Allergy Appl Immunol 120, 218-24

Feliziani V, Lattuada G, Parmiani S, Dall'Aglio PP (1995). Safety and efficacy of sublingual rush immunotherapy with grass allergen extracts. A double blind study. Allergol Immunopathol (Madr) 23, 224- 30

Fukushima Y, Kawata Y, Mizumachi K, Kurisaki J, Mitsuoka T (1999). Effect of bifidobacteria feeding on fecal flora and production of immunoglobulins in lactating mouse. Int J Food Microbiol 46, 193-197

Fuller R (1991). Probiotics in human medicine. Gut 32, 439-4429

Geuking MB, Cahenzli J, Lawson MA, Ng DC, Slack E, Hapfelmeier S, et al (2011). Intestinal bacterial coloni- zation induces mutualistic regulatory $\mathrm{T}$ cell responses. Immunity 27, 794-806

Gorissen DM, Rutten NB, Oostermeijer CM, Niers LE, Hoekstra MO, Rijkers GT, et al (2014). Preventive effects of selected Probiotics strains on the development of asthma and allergic rhinitis in childhood. The Panda study. Clin Exp Allergy 4, 1431-3.

Guez S, Vatrinet C, Fadel R, André C (2000). House dust mite sublingual swallow immunotherapy in perennial rhinitis: a double blind placebo controlled study. Allergy 55, 369-75

Hirsch T, Sahn M, Leupold W (1997). Double blind placebo controlled study of sublingual immunotherapy with house dust mite extracts in children. Pediatr Allergy Immunol 8, 21-7

Horak F, Stubner UE, Berger U, Marks B, Toth J, Jager S (1998). Immunotherapy with sublingual birch pollen extract: a short term double blind study. J Investig Allergol Clin Immunol 8, 165-71

Hordijk GJ, Antwelink JB, Luwema RA (1998). Sublingual immunotherapy with a standardized grass pollen extract: a double blind placebo controlled study. Allergol Immunopathol 26, 234-40

Isolauri E, Arvola T, Sütas Y, Moilanen E, Salminen S (2000). Probiotics in the management of atopic eczema. Clin Exp Allergy 30, 1604-1610.

Isolauri E (2001). Probiotics in human disease. Am J Nutr 73, 1142S 46S

Kirjavainen PV, Apostolou E, Salminen SJ, Isolauri E (1999). New aspects of probiotics a novel approach in the management of food allergy. Allergy 54, 909-915

La Rosa M, Ranno C, André C, et al (1999). Double blind placebo controlled evaluation of sublingual swallow immunotherapy with standardized parietaria judaica extract in children with allergic rhinoconjunctivitis. J Allergy Clin Immunol 104, 425-32

Lichtenstein LM, Ishizaka K, Norman PS, et al (1973). $\mathrm{IgE}$ antibody measurements in ragweed hay fever. Relationship to clinical severity and the results of immunotherapy. J Clin Invest 52, 472-82

Lima MT, Wilson D, Pitkin L, et al (2002). Grass pollen sublingual immunotherapy for seasonal rhinoconjunctivitis: a randomized controlled trial. Clin Exp Allergy 32, 507-14

Lombardi C, Gargioni S, Venturi S, Zoccali P, Canonica GW, Passalacqua G (2001). Controlled study of preseasonal immunotherapy with grass pollen extract in tablets: effect on bronchial hyperreactivity. J Investig Allergol Clin Immunol 11, 41-5

Matricardi PM, Bjorksten B, Bonini S, Bousquet J, Djukanovic R, Dreborg S, Gereda J, Malling H-J, Popov T, Raz E, renz H (2003). Microbial products in allergy prevention and therapy. Allergy 58, 461-71 
Matsuzaki, chin J (2000). Modulating immune response with Probiotics bacteria. Immunol and Cell Biol 78, 67-73

Moingeon P, Batard T, Fadel R, Frati F, Sieber J, Van Overtvelt L (2006). Immune mechanisms of allergenspecific sublingual immunotherapy. Allergy 61, 151165

Moingeon P, Mascarell L (2012). Induction of tolerance via the sublingual route: mechanisms and applications. Clin Dev Immunol 623474

Niers LE, Hoekstra MO, Timmerman HM, van Uden NO, de Graaf PM, Smits HH (2007). Selection of Probiotics bacteria for prevention of allergic diseases: immunomodulation of neonatal dendritic cells. Clin Exp Immunol 149, 344-52

Niers LE, Timmerman HM, Rijkers GT, van Bleek GM, van Uden NO, Knol EF, et al (2005). Identification of strong interleukin-10 inducing lactic acid bacteria which down-regulate $\mathrm{T}$ helper type 2 cytokines. Clin Exp Allergy 35, 1481-9

Paganelli R, Ciuffreda S, Verna N, Cavallucci E, Paolini F, Ramondo S et al (2002). Probiotics and foodallergic diseases. Allergy 57, 97-99

Pajno GB, Morabito L, Barberio G, Parmiani S (2000). Clinical and immunological effects of longterm sublingual immunotherapy in asthmatic children sensitized to mite: a double blind study. Allergy 55, 842-9

Passalacqua G, Albano M, Fregonese L, et al (1998). Randomised controlled trial of local allergoid immunotherapy on allergic inflammation in miteinduced rhinoconjunctivitis. Lancet 351, 629-32

Passalacqua G, Albano M, Riccio AM, et al (1999). Clinical and immunological effects of a rush sublingual immunotherapy to parietaria species: a double blind placebo controlled trial. J Allergy Clin Immunol 104, 964-8

Pfaar O, Cazan D, Klimek L, Larenas-Linnemann D, Calderon M (2012). Adjuvants for immunotherapy. Curr Opin Allergy Clin Immunol 12, 648-657

Pradalier A, Basset D, Claudel A, et al (1999). Sublingual swallow immunotherapy (SLIT) with a standardized five grass pollen extract (drops and sublingual tablets) versus placebo in seasonal rhinitis. Allergy 54, 819-28

Price DB, Rigazio A, Campbell JD, Bleecker ER, Corrigan CJ, Thomas M, Wenzel SE, Wilson AM, Small MB, Gopalan G, Ashton VL, Burden A, Hillyer EV, Kerkhof M, Pavord ID (2015).Blood eosinophil count and prospective annual asthma disease burden: a UK cohort study. Lancet Respir Med 3, 849-58

Purello D'Ambrosio F, Gangemi S, Isola S, et al (1999). Sublingual immunotherapy: a double blind placebo controlled trial with Parietaria judaica extract standardized in mass units in patients with rhinoconjunctivitis, asthma or both. Allergy 54, 968-73
Quirino T, Iemoli E, Siciliani E, Parmiani S, Milazzo F (1996). Sublingual versus injective immunotherapy in grass pollen allergic patients: a double blind (double dummy) study. Clin Exp Allergy 26, 1253-61

Radulovic S, Jacobson MR, Durham SR, Nouri-Aria KT (2008). Grass pollen immunotherapy induces Foxp3expressing CD4+ CD25+ cells in the nasal mucosa. $\mathrm{J}$ Allergy Clin Immunol 121, 1467-1472

Sabbah A, Hassoun S, Le Sellin J, Andre C, Sicard H (1994). A double-blind, placebo-controlled trial by the sublingual route of immunotherapy with a standardized grass pollen extract. Allergy 49, 309-13

Scadding GW, Shamji MH, Jacobson MR, et al (2010). Sublingual grass pollen immunotherapy is associated with increases in sublingual Foxp3-expressing cells and elevated allergen-specific immunoglobulin G4, immunoglobulin A and serum inhibitory activity for immunoglobulin E-facilitated allergen binding to $\mathrm{B}$. Clin Exp Allergy 40, 598-606

Secrist H, Dekruyff RH, Umetsu DT (1995). Interleukin 4 production by $\mathrm{CD} 4+\mathrm{T}$ cells from allergic individuals is modulated by antigen concentrations and antigen presenting cell type. J Exp Med 181, 1081-9

Silvestri M, Spallarossa D, Battistini E, et al (2002). Changes in inflammatory and clinical parameters and in bronchial hyperreactivity asthmatic children sensitized to house dust mites following sublingual immunotherapy. J Invest Allergol Clin Immunol 12, $52-9$

Sudo N, Sawamura S, Tanaka K, Aiba Y, Kubo C, Koga Y (1997). The requirement of intestinal bacterial flora for the development of an IgE production system fully susceptible to oral tolerance induction. J Immunol 5, 1739-45

Tari MG, Mancino M, Monti G (1990). Efficacy of sublingual immunotherapy in patients with rhinitis and asthma due to house dust mite. A double-blind study. Allergol Immunopathol (Madr) 18, 277-84

Troise C, Voltolini S, Canessa A, Pecora S, Negrini AC (1995). Sublingual immunotherapy in Parietaria pollen-induced rhinitis: a double-blind study. J Investig Allergol Clin Immunol 5, 25-30

Upton MN, Mcconnachie A, Mcsharry C, Hart CL, Smith GD, Gillis CR (2000). Intergenerational 20 year trends in the prevalence of asthma and hay fever in adults: the Midspan family study surveys of parents and offspring. BMJ 321, 88-92

Varney VA, Hamid QA, Gaga M (1993). Influence of grass pollen immunotherapy on cellular infiltration and cytokine mRNA expression during late phase cutaneous response. J Clin Invest 92, 644-50

Voltolini S, Modena P, Minale P, et al (2001). Sublingual immunotherapy in tree pollen allergy: double blind, placebo controlled study with a biologically standardized extract of tree pollen (alder, 
birch and hazel) administered by a rush schedule. Allergol Immunopathol 29, 103-10

Vourdas D, Syrigou E, Potamianou P, et al (1998). Double blind placebo controlled evaluation of sublingual immunotherapy with a standardized olive tree pollen extract in pediatric patients with allergic rhinoconjunctivitis and mild asthma due to olive tree pollen sensitization. Allergy 53, 662-71

Wu CT, Chen PJ, Lee YT, Ko JL, Lue KH (2016). Effects of immunomodulatory supplementation with Lactobacillus rhamnosus on airway inflammation in a mouse asthma model. J Microbiol Immunol Infect 49, 625-35 